удК 349.2

DOI https://doi.org/10.32837/apdp.v0i86.2402

О. А. Губська

\title{
НЕДОЛІКИ ТА ПРОГАЛИНИ ЗАКОНОДАВСТВА У СФЕРІ ПРАЦЕВЛАШТУВАННЯ ДЕРЖАВНИХ СЛУЖБОВЦІВ В УМОВАХ ЄВРОІНТЕГРАЦІЇ УКРАЇНИ
}

Державна кадрова політика у сфері працевлаштування державних службовців є індикатором розвитку суспільства. Як влучно відзначає Ю.В. Ковбасюк, поки в нашій державі не складеться справді демократичної, соціально спрямованої ефективної кадрової політики в системі державного управління, Україна не посяде чільного місця серед країн європейської спільноти [1]. Україна як незалежна й демократична держава натепер перебуває на складному та важливому етапі свого розвитку. У такі часи актуальності набуває увага до проблем, пов'язаних із категоріями осіб, які у своїй професійній діяльності реалізовують власну компетентність від імені держави. За таких умов важливим є поповнення кадрового потенціалу державної служби висококваліфікованими фахівцями, які за допомогою практичного досвіду, правових та професійних знань, а також бажання реалізувати своє право на працю сприятимуть вирішенню поставлених перед державою завдань.

Від початку цивілізованого розвитку суспільства вирішення практичних завдань, що постають перед державою, належить підготовленому складу працівників різних сфер та напрямів його життєдіяльності. Одна з визначальних ролей належить суб'єктам, які формують державну політику й управляють процесами їі реалізації. За таких умов правове регулювання їх працевлаштування є важливою складовою частиною політики держави, що являє собою її головний напрям щодо підготовки та добору кадрів. Проте натепер очевидною є недостатня увага до недоліків вказаного інституту, що може призвести до відсутності кваліфікованого кадрового потенціалу у країні чи зниження його професійного рівня, що актуалізує необхідність дослідження проблем, пов'язаних із працевлаштуванням державних службовців, та пошук шляхів їх вирішення.

Питання недоліків правового регулювання працевлаштування державних службовців малодосліджене у вітчизняній науці. На окремі проблемні аспекти вступу на державну службу звертали увагу такі вчені: О.Я. Баранська, Ю.П. Битяк, Т.Ю. Витко, Н.Т. Гончарук, М.В. Канавець, Ю.В. Ковбасюк, І.Б. Коліушко, І.П. Лопушинський, В.Я. Малиновський, В.М. Мартиненко, О.Ф. Мельников, О.Ю. Оболенський, В.М. Олуйко, Л.В. Романюк, В.П. Тимощук, О.Ю. Шапран та інші. Проте жоден із зазначених науковців не здійснював комплексного дослідження та виділення проблем правового регулювання працевлаштування державних службовців. Окрім того, низка проблемних питань, необхідність вирішення яких підкреслюється вітчизняними вченими, стосуються норм законодавства, що втратило чинність. Саме тому важливе вивчення саме тих проблем правового регулювання працевлаштування державних службовців, які характерні для сучасного етапу розвитку даного інституту. 
Аналіз юридичної літератури засвідчив наявність позитивних тенденцій, що вказували на початок вирішення тих проблем, які виділяли науковці в часи чинності законодавства про державну службу попередніх років. Свідченням цього процесу було, зокрема, ухвалення Концепції Державної цільової програми розвитку державної служби на період до 2016 р., у якій до основних причин недостатньої ефективності управління людськими ресурсами на державній службі та залучення громадян до державної служби було віднесено: 1) невідповідність стандартів та процедур управління персоналом на державній службі європейським практикам; 2) відсутність взаємозв'язку системи класифікації посад державної служби та вимог, що висуваються до професійної компетентності для зайняття таких посад; 3) недостатнє застосування наукових підходів, результатів наукових досліджень для управління людськими ресурсами на державній службі; 4) недостатню відкритість і прозорість системи державної служби, слабкий контроль інститутів громадянського суспільства за виконанням державних функцій та завдань державними органами, органами влади Автономної Республіки Крим [2]. На перший погляд дані проблеми є досить загальними та не стосуються інституту працевлаштування державних службовців. Проте кожна з них має негативні наслідки для регулювання вступу на державну службу. Наприклад, проблема невідповідності стандартів та процедур управління персоналом на державній службі європейським практикам є характерною практично для всіх правових інститутів України, сформованих наприкінці минулого століття та на початку поточного. Окрім того, кожна галузь права потребує імплементації європейських стандартів у контексті спрямованості зовнішньої політики держави на євроінтеграцію.

Інша проблема - відсутність взаємозв'язку системи класифікації посад державної служби та вимог, що висуваються до професійної компетентності для зайняття таких посад, на нашу думку, не вирішена і натепер. Вимоги до кандидатів на вступ до державної служби не передбачають наявності спеціалізованої вищої освіти, вони обмежуються лише вказівкою на їі ступінь. Наприклад, особа, якій присвоєно ступінь вищої освіти в технічних галузях, може вступити на державну службу на посади, що потребують відповідних економічних, юридичних тощо знань. У такому разі постає питання про необхідність закріплення вимог щодо спеціальної вищої освіти або, що вбачаємо більш логічним підходом, щодо встановлення для державних службовців обов'язкової підготовчої служби впродовж певного періоду. I лише після завершення такої служби особа може претендувати на постійну посаду згідно з результатами участі в конкурсі.

Проблема недостатнього застосування наукових підходів та результатів наукових досліджень для управління людськими ресурсами на державній службі не $є$ недоліком правового регулювання, проте їі подолання позитивним чином могло б вплинути на вирішення проблем працевлаштування державних службовців. На актуальності цієї проблеми наголошується і в науковій літературі. Зокрема, Т.Ю. Витко звернула увагу на особливості процедури конкурсного відбору державних службовців, зазначила водночас, що «сучасний стан кадрового забезпечення характеризується необ'єктивною та непрозорою конкурсною процедурою. Він переважно має формальний характер, адже досить часто його оголошують 
для того, щоб «потрібного» кандидата в межах чинного законодавства призначити на «потрібну» посаду. Переважно в конкурсі перемагає не та особа, яка є найбільш придатною для виконання завдань, що висуває вакантна посада, а «потрібний» кандидат» [3, с. 10]. Вирішення проблеми прозорості та недостатнього громадського контролю нині здійснюється, зокрема, у ст. 27 Закону України «Про державну службу» від 10 грудня 2015 р. № 889-VIII [4]. Так, до складу конкурсної комісії можуть залучатися на конкурсній основі представники громадських об'єднань, а до їі роботи - державні службовці, зокрема й з інших державних органів, науковці й експерти у відповідній сфері, а також представник виборного органу первинної профспілкової організації. Тобто загалом такий склад комісії значно зменшує шанси для корупційних дій заінтересованих осіб, оскільки більшість ії складу не можуть мати особистої зацікавленості у вирішенні кадрових питань державної служби вигідним для окремих суб'єктів способом. Залучення науковців та експертів підвищує вірогідність ухвалення комісією об'єктивного та найбільш виваженого рішення. Тому, резюмуючи, можна зробити висновок, що проблеми, відзначені законодавцем у Концепції Державної цільової програми розвитку державної служби на період до 2016 р., були частково вирішені, проте окремі питання все ще потребують уваги законодавця.

На підставі аналізу наукової літератури можемо стверджувати, що найбільш поширеним поглядом на проблеми правового регулювання працевлаштування державних службовців є група загальних та не повною мірою актуальних позицій, які полягають у тому, що положення попередніх редакцій Закону України «Про державну службу» не відповідали вимогам сучасності й міжнародним стандартам, а сама система державної служби вважалась недосконалою, застарілою та такою, що є одним із чинників, які стримують успішне проведення реформ [5, с. 7; 6, с. 3]. Практично кожен науковець, який здійснював аналіз проблемних питань правового регулювання державної служби, вказував на недосконалість поточного законодавчого регулювання, а шляхи вирішення проблеми вбачав в ухваленні нового Закону України «Про державну службу». Водночас, як демонструє аналіз чинної редакції Закону, вітчизняний законодавець грунтовно підійшов до регламентації питань, пов'язаних із вступом на державну службу, та фактично усунув ті проблеми, на які зверталась увага науковцями.

У процесі дослідження нами виділені такі недоліки та прогалини законодавства у сфері працевлаштування державних службовців:

1) відсутність оцінювання індивідуальних психологічних особливостей, фізичної придатності та стану здоров'я кандидатів на зайняття посад державної служби;

2) відсутність чітких вимог щодо професійно-кваліфікаційних характеристик посад державної служби, яким повинен відповідати кандидат на державну посаду;

3) проблема іноземного громадянства державних службовців, подвійного громадянства чи участі в заборонених в Україні терористичних організаціях;

4) проблема політичного впливу на державних службовців;

5) проблема дотримання військового законодавства державними службовцями з огляду на складну військово-політичну ситуацію в нашій державі. 
Вирішення кожної із зазначених проблем потребує формулювання чітких пропозицій та пошуку відповідних шляхів. Так, першим недоліком правового регулювання працевлаштування державних службовців нами виділено відсутність оцінювання індивідуальних психологічних особливостей, фізичної придатності та стану здоров'я кандидатів на посаду держслужбовця. Наявність такої проблеми зазначала Т.Ю. Витко [3, с. 11], проте ми пропонуємо розглядати її значно ширше. О.Ю. Шапран висувала пропозицію встановити вимогу для кандидатів щодо подання разом з іншими документами медичної довідки [7, с. 104], але такий шлях вирішення є сумнівним з огляду на корупційність системи охорони здоров'я в Україні. Вбачаємо дві можливості для вирішення даної проблеми:

1) як зазначає I.П. Лопушинський, у Бельгії, Швеції та Нідерландах для перевірки фізичної (медичної) придатності для зайняття певної посади існує спеціальна медична служба [8, с. 89]. Пропонуємо створення такої ж служби за внесення таких змін у чинне законодавство:

а) п. 4 Положення про Національне агентство України з питань державної служби [9] доповнити підпунктом такого змісту: «Здійснює перевірку фізичної (медичної) придатності кандидатів на зайняття вакантних посад державної служби»; п. 5 доповнити таким підпунктом: «Створює спеціальну медична службу для перевірки фізичної (медичної) придатності кандидатів на зайняття вакантних посад державної служби»;

б) ч. 3 ст. 22 Закону України «Про державну службу» від 10 грудня 2015 р. № 889-VIII [4] доповнити підпунктом «Порядок перевірки фізичної (медичної) придатності кандидатів на зайняття вакантних посад державної служби»; ст. 26 Закону доповнити ще однією частиною такого змісту: «Медична служба здійснює перевірку фізичної (медичної) придатності кандидатів на зайняття вакантних посад державної служби»;

в) узгодити 3 вищезазначеними змінами Порядок проведення конкурсу на зайняття посад державної служби [10];

2) другий варіант є значно простішим, адже передбачає лише перевірку відповідності індивідуальних психологічних особливостей кандидата на публічну службу вимогам професійно-посадової діяльності в органах влади. У такому разі достатнім є залучення до конкурсної комісії фахівця, який оцінює, діагностує і вивчає поведінку й розумові процеси. Для реалізації даного шляху вирішення проблеми пропонується внести такі зміни до Закону України «Про державну службу» від 10 грудня 2015 р. № 889-VIII [4]:

а) ч. 3 ст. 22 доповнити підпунктом «Порядок перевірки індивідуальних психологічних особливостей кандидата на публічну службу»;

б) ст. 27 доповнити частиною такого змісту: «До роботи конкурсної комісії залучається спеціаліст, що має завершену вищу психологічну освіту або пройшов перепідготовку на базі вищої освіти за спеціальністю «психологія» ;

в) узгодити з вищезазначеними змінами Порядок проведення конкурсу на зайняття посад державної служби [10].

Отже, проблема відсутності оцінювання індивідуальних психологічних особливостей, фізичної придатності та стану здоров'я кандидатів на посади державної 
служби полягає в необхідності перевірки не лише професійних якостей, а й фізіологічної здатності працівника виконувати покладені на нього функції. Вирішення вбачаємо у двох можливих напрямах - простому та складному. Вибір простого шляху полягає у проведенні співбесіди з фахівцем, який оцінює, діагностує і вивчає поведінку та розумові процеси. Запропонований складний шлях зумовлює створення спеціальної медичної служби для проведення повної перевірки здоров’я працівників. Такий напрям досконаліший, проте сумнівно, що в сучасних реаліях можливий для втілення в Україні.

Наступна проблема - відсутність чітких вимог щодо професійно-кваліфікаційних характеристик посад державної служби, яким повинен відповідати кандидат на посаду держслужбовця. Ї̈̈ сутність полягає в тому, що у вимогах до кандидатів на вступ до державної служби не зазначаються вимоги щодо спеціалізації вищої освіти, міститься лише вказівка на її ступінь, а сам перелік вимог до кандидата являє собою зазначення умов, за яких особа не має права на вступ. Це надає можливість широкому колу осіб обрати працю державного службовця та реалізувати себе, здійснюючи обов'язки від імені держави, проте не сприяє формуванню якісного кадрового складу державної служби. Законодавець спробував вирішити дану проблему шляхом встановлення можливості випробувального терміну строком до шести місяців із метою перевірки відповідності державного службовця займаній посаді [4]. Проте вважаємо, що вирішення даної проблеми має бути радикальним. Тому пропонуємо, окрім випробувального терміну, встановити обов'язкове проходження підготовчої служби протягом певного періоду, у результаті якого особа зможе претендувати на постійну посаду. Як зазначає І.П. Лопушинський, відповідно до Федерального закону Німеччини про чиновників для роботи на посадах середнього службового рівня, вимагається підготовча служба впродовж одного року, а на посадах підвищеного службового рівня - протягом трьох років [8, с. 89]. Подібну практику варто запровадити і в Україні, для чого пропонуємо доповнити гл. 3 Закону України «Про державну службу» від 10 грудня 2015 р. № 889-VIII [4] статтею такого змісту: «Підготовча служба. 1. У разі призначення особи на посаду державної служби вперше в акті про призначення на посаду суб'єкт призначення встановлює підготовчу службу з метою перевірки відповідності державного службовця займаній посаді із зазначенням її строку. 2. Підготовча служба в разі призначення на посаду державної служби категорії «А» встановлюється строком до трьох років. 3. Підготовча служба в разі призначення на посаду державної служби всіх інших категорій встановлюється строком до одного року. 4. У разі незгоди особи з рішенням про встановлення підготовчої служби, вона вважається такою, що відмовилася від зайняття посади державної служби. За таких обставин застосовується відкладене право другого за результатами конкурсу кандидата на зайняття вакантної посади державної служби. Якщо конкурсною комісією такого кандидата не визначено, проводиться повторний конкурс. 5. Якщо державний службовець у період підготовчої служби був відсутній на роботі у зв'язку з тимчасовою непрацездатністю, перебуванням у додатковій відпустці у зв'язку з навчанням або з інших поважних причин, строк підготовчої служби продовжується на відповідну кількість днів, протягом яких він фактично не виконував посадові обов'язки. 
6. Суб'єкт призначення має право звільнити державного службовця з посади до закінчення строку підготовчої служби в разі встановлення невідповідності державного службовця займаній посаді на підставі п. 2 ч. 1 ст. 87 цього Закону. Суб'єкт призначення попереджає державного службовця про звільнення в письмовій формі не пізніш як за сім календарних днів із зазначенням підстав невідповідності займаній посаді. 7. У разі, якщо строк підготовчої служби закінчився, а державного службовця не ознайомлено з наказом про його звільнення з посади державної служби, він уважається таким, що пройшов підготовчу службу» .

Водночас проходження підготовчої служби не виключає можливості призначення випробувального терміну для державного службовця. Підготовчою службою є процес набуття необхідних навичок та знань, тоді як випробувальний термін це перевірка здатності їх реалізації на практиці. Тому вважаємо, що підготовча служба має передувати випробувальному терміну, проходження якого засвідчує готовність працівника до вступу на посаду державної служби.

Отже, вирішення проблеми відсутності чітких вимог щодо професійно-кваліфікаційних характеристик посад державної служби, яким повинен відповідати кандидат до державної служби, ми вбачаємо в необхідності регламентації інституту підготовчої служби. Підготовча служба є обов'язковою в разі призначення особи на посаду державної служби вперше, по своїй суті є близькою до випробування. Принципова різниця полягає у процесі набуття необхідних навичок та знань і більшому строку проходження. Інститут підготовчої служби покликаний надати особі, яка претендує на ту чи іншу посаду, ґрунтовні знання та сформувати навички у відповідній сфері.

Наступна проблема є комплексною і водночас стосується наявності іноземного громадянства в кандидатів на посаду держслужбовця, подвійного громадянства, забороненого в Україні, чи участі в заборонених в Україні терористичних організаціях.

Вирішення проблеми наявності іноземного громадянства в державних службовців у контексті євроінтеграційних процесів в Україні та наявного досвіду залучення до державної служби іноземців вбачаємо в наданні можливості громадянам Європейського Союзу брати участь у конкурсах на вступ до державної служби в Україні на загальних підставах. Тому пропонуємо внести зміни до п. 6 ч. 2 ст. 19 Закону України «Про державну службу» від 10 грудня 2015 р. № 889-VIII [4] та регламентувати його так: «<...> має громадянство іншої держави, окрім громадянства однієї з держав-членів Європейської співдружності». Це дозволить на законних підставах залучати до державної служби іноземних громадян, які володіють необхідними навичками та знаннями й виявили бажання їх реалізувати на посаді державної служби в Україні. Проте даний момент зумовлює проблематику в частині вимоги щодо вільного володіння державним службовцем державною мовою, тому пропонується внести зміни до ч. 1 ст. 19 Закону України «Про державну службу» від 10 грудня 2015 р. № 889-VIII [4], викласти її в такій редакції: «Право на державну службу мають повнолітні громадяни України, які вільно володіють державною мовою, громадяни однієї з держав-членів Європейської співдружності та яким присвоєно ступінь вищої освіти не нижче <...>». Також для вирішення «мовної» 
проблеми державних службовців - іноземних громадян варто змінити вимоги до осіб, які претендують на вступ на державну службу. Пропонуємо доповнити п. п. 2-5 ч. 2 ст. 20 Закону України «Про державну службу» від 10 грудня 2015 р. № 889-VIII [4] вимогою «володіння іноземною мовою, яка є однією з офіційних мов Ради Європи», що означатиме можливість вступу таких державних службовців на посади не лише категорії «A», а й категорій «Б» та «B».

Проблему подвійного громадянства, громадянства невизнаних держав та членства в терористичних організаціях неможливо подолати суто нормативним шляхом. Для її вирішення необхідна взаємодія дипломатичних представництв, Служби безпеки України та громадянського суспільства з метою запобігання можливості працевлаштування таких осіб на посади державної служби. 3 нормативного погляду пропонується доповнити ч. 2 ст. 19 Закону України «Про державну службу» від 10 грудня 2015 р. № 889-VIII [4] підпунктами «Має подвійне громадянство» та «Має належність до організацій, заборонених у судовому порядку або законодавством» .

Зважаючи на характер зазначеної проблеми, необхідне встановлення санкцій за приховування такої інформації. Тому пропонуємо внести зміни до ч. 1 ст. 83 Закону України «Про державну службу» від 10 грудня 2015 р. № 889-VIII [4]: «1. Державна служба припиняється: <...> у разі приховування інформації про іноземне громадянство, окрім громадянства однієї з держав-членів Європейської співдружності, подвійне громадянство чи належність до організацій, заборонених у судовому порядку або законодавством» .

Отже, проблема іноземного громадянства в кандидатів на посаду в державній службі, подвійного громадянства, забороненого в Україні, чи участі в заборонених в Україні терористичних організаціях може бути вирішена суто комплексно, проте з нормативного погляду можливим є встановлення відповідних обмежень під час прийняття на державну службу. Важливим шляхом вирішення вбачаємо надання можливості рівного доступу до державної служби в Україні не лише власних громадян, а й громадян держав-членів Європейського Союзу. Даний процес став звичним для України останніми роками, тому натепер більш логічною є його законодавча регламентація, аніж постійне порушення норм Закону України «Про державну службу» від 10 грудня 2015 р. № 889-VIII [4].

Проблема політичного впливу на державних службовців залишається актуальною протягом багатьох років. Так, натепер Закон України «Про державну службу» від 10 грудня 2015 р. № 889-VIII [4] не містить вимоги заборони прийняття на державну службу членів політичних партій, обмеження стосуються виключно службовців категорії «А». Для вирішення даної проблеми пропонуємо: 1) доповнити ст. 19 Закону України «Про державну службу таким: «<..> На державну службу не може вступити особа, яка: <...>€ членом політичної партії чи суміщає державну службу зі статусом депутата місцевої ради»; 2) внести зміни до ст. 10 Закону України «Про державну службу» такого змісту: «Державний службовець не має права: $<$...> бути членом політичної партії; <...> суміщати державну службу зі статусом депутата місцевої ради»; 3) узгодити із зазначеними змінами Порядок проведення конкурсу на зайняття посад державної служби [10]. 
Отже, на наш погляд, проблема політичного впливу на державних службовців може бути вирішена лише шляхом радикального обмеження можливості державних службовців здійснювати політичну діяльність. Неприпустиме здійснення політичного тиску на таких осіб або ж їх зосередження на виконанні функцій, не передбачених займаною посадою. Тому всі кандидати на посаду державних службовців повинні від початку бути рівними в умовах та звільненими від будь-якого політичного впливу.

Виділення останньої проблеми обумовлюємо складною військово-політичною ситуацією в нашій державі. Ідеться про дотримання військового законодавства державними службовцями. Ї̈̈ суть полягає в тому, що в сучасних умовах претендент на посаду державної служби чоловічої статі повинен пройти військову службу або бути звільненим від неї згідно з нормами чинного законодавства. Водночас неприпустиме звільнення від військової служби через виконання певних обов'язків. Так, відповідно до ч. 5 ст. 30 Закону України «Про статус депутатів місцевих рад» від 11 липня 2002 р. № 93-IV [11], на час виконання депутатських повноважень депутату місцевої ради надається відстрочка від призову на строкову військову чи альтернативну (невійськову) службу. Такий підхід є нераціональним, адже суперечить самій сутності державної служби, яка грунтується на служінні народу України, відданості справі, персональній відповідальності за виконання службових обов'язків, а отже, і на виконанні завдань і функцій держави. Тому в умовах військової агресії та негативних перспектив щодо загострення ситуації державні службовці чоловічої статі не лише не повинні звільнятись від військової служби, а мають обов'язково виконувати цей почесний конституційний обов'язок. Вирішення даної проблеми пропонуємо здійснити шляхом вилучення ч. 5 ст. 30 зі змісту Закону України «Про статус депутатів місцевих рад» від 11 липня 2002 р. № 93-IV [11] та внесення змін до Закону України «Про державну службу» від 10 грудня 2015 р. № 889-VIII [4]: 1) ч. 2 ст. 19 Закону доповнити таким: «Особа чоловічої статі, яка не пройшла строкову військову чи альтернативну (невійськову) службу та не може бути звільненою від неї згідно з нормами чинного законодавства <...>».

Натепер ситуація склалась таким чином, що особи, які пройшли строкову військову чи альтернативну (невійськову) службу, не отримують жодних переваг у разі вступу на державну службу. Навіть більше, окремі категорії осіб можуть отримати відстрочку від її проходження через «непорушність» їхніх повноважень. Єдиним шляхом вирішення досліджуваної проблеми є встановлення обов'язкового проходження військової служби для підтвердження на практиці бажання приносити користь державі та готовності працювати на її благо.

Висновки. Підсумовуючи результати дослідження, можемо стверджувати, що на нинішньому етапі питання правового регулювання працевлаштування державних службовців є найбільш досконалим за весь період незалежності України. У зв'язку із цим виділення проблемних моментів його правового регулювання є питанням, що характеризується втратою актуальності більшості наукових праць, пов'язаних із ним. Сам механізм вступу на державну службу тривалий період характеризувався наявністю однієї глобальної проблеми - «недосконалості правового регулювання». Проте останні реформи державної служби наблизили 
законодавчу регламентацію працевлаштування державних службовців до європейських стандартів. Тому наявні концепції проблематики даного питання потребують суттєвого перегляду та зміни підходів щодо пошуку недоліків.

Неправильним є твердження, що всі проблеми вже подолані, а правове регулювання відповідного інституту здійснюється належним чином. Пошук недоліків натепер варто здійснювати щодо вимог, які висуваються до кандидатів на посаду держслужбовця. Поліпшення рівня регулювання даної сфери, оплати праці, автоматизація багатьох процесів зумовлюють підвищення стандартів щодо осіб, які у своїй професійній діяльності здійснюють повноваження, безпосередньо пов'язані з виконанням завдань і функцій державного органу. Наявні проблеми не є масштабними, а отже, їх подолання є цілком реальним у найближчому майбутньому.

\section{Jimepamypa}

1. Ковбасюк Ю.В. Сучасна кадрова політика в державному управлінні. Віче. 2011. № 2. URL: http://www.viche.info/journal/2380.

2. Про схвалення Концепції Державної цільової програми розвитку державної служби на період до 2016 р. : розпорядження Кабінету Міністрів України від 27 червня 2012 р. № 411-р. Офіиійний вісник України. 2012. № 50. С. 504. Ст. 1988. Код акта 62322/2012.

3. Витко Т.Ю. Державна кадрова політика України: сутність, сучасний стан і перспективи розвитку. Теорія та практика державного управління і місцевого самоврядування. 2016. № 1 . URL: http://el-zbirn-du.at.ua/2016_1/3.pdf.

4. Про державну службу : Закон України від 10 грудня 2015 p. № 889-VIII. Відомості Верховної Ради України. 2016. № 4. Ст. 43.

5. Канавець М.В. Актуальні проблеми формування засад державної кадрової політики в Україні. Державне будівництво. 2013. № 2. URL: http://www.kbuapa.kharkov.ua/e-book/db/2013-2/doc/3/05.pdf.

6. Тертишна О.В. Стан та перспективи розвитку державної служби в Україні в контексті адаптації до стандартів ЄС. Державне управління та місиеве самоврядування : збірник наукових праць. 2009. Вип. 1. URL: http://www.dridu.dp.ua/vidavnictvo/2009/2009-01(1)/Tertishna.pdf.

7. Шапран О.Ю. Перспективи розвитку державної служби в Україні у контексті запровадження нового законодавства про державну службу. Вісник Національної академії державного управління при Президентові України. 2014. № 3. С. 99-108.

8. Лопушинський І.П. Вступ на публічну службу: європейський досвід для України. Державна служба. 2011. № 7. С. 82-90.

9. Про затвердження Положення про Національне агентство України з питань державної служби : постанова Кабінету Міністрів України від 1 жовтня 2014 р. № 500. URL: http://zakon3.rada.gov.ua/ laws/show/500-2014-\% D0\% BF.

10. Про затвердження Порядку проведення конкурсу на зайняття посад державної служби : постанова Кабінету Міністрів України від 25 березня 2016 р. № 246. Офіиійний вісник України. 2016. № 28. С. 179. Ст. 1116.

11. Про статус депутатів місцевих рад : Закон України від 11 липня 2002 р. № 93-IV. Відомості Верховної Ради України. 2002. № 40. Ст. 290. 


\section{Анотація}

Губська О. А. Недоліки та прогалини законодавства у сфері працевлаштування державних службовців в умовах євроінтеграції України. - Стаття.

У статті проаналізовано специфіку теоретичних і практичних проблем правового регулювання працевлаштування державних службовців. Виявлено недоліки та прогалини законодавства у сфері працевлаштування державних службовців в умовах євроінтеграції України. Наприклад, автором виділено такі проблеми: невідповідність стандартів та процедур управління персоналом на державній службі європейським практикам; відсутність взаємозв'язку системи класифікації посад державної служби та вимог, що висуваються до професійної компетентності для зайняття таких посад; недостатнє застосування наукових підходів та результатів наукових досліджень для управління людськими ресурсами на державній службі тощо.

Аналіз юридичної літератури засвідчив наявність позитивних тенденцій, що вказували на початок вирішення тих проблем, які виділяли науковці в часи чинності законодавства про державну службу попередніх років. Свідченням цього процесу було, зокрема, ухвалення Концепції Державної цільової програми розвитку державної служби на період до 2016 року, у якій було виокремлено основні причини недостатньої ефективності управління людськими ресурсами на державній службі та залучення громадян до державної служби.

Автор виділив недоліки та прогалини законодавства у сфері працевлаштування державних службовців, як-от: 1) відсутність оцінювання індивідуальних психологічних особливостей, фізичної придатності та стану здоров'я кандидатів на зайняття посад державної служби; 2) відсутність чітких вимог щодо професійно-кваліфікаційних характеристик посад державної служби, яким повинен відповідати кандидат на посаду держслужбовця; 3) проблема іноземного громадянства державних службовців, подвійного громадянства чи участі в заборонених в Україні терористичних організаціях; 4) проблема політичного впливу на державних службовців; 5) проблема дотримання військового законодавства державними службовцями з огляду на складну військово-політичну ситуацію в нашій державі. Сформульовано обгрунтовані пропозиції щодо шляхів їх вирішення.

Ключові слова: проблеми, недоліки, прогалини, працевлаштування, державні службовці, державна служба.

\section{Summary}

Hubska O. A. Shortcomings and gaps in the legislation in the field of employment of civil servants in the context of Ukraine's European integration. - Article.

In the article the specifics of theoretical and practical problems of legal regulation of employment of civil servants are analyzed. The author made an analysis of the legal literature, which showed the presence of positive trends that indicated the beginning of the solution of those problems that were identified by scientists during the legislation on civil service in previous years. In particular, the adoption of the Concept of the State Targeted Program for the Development of the Civil Service for the period up to 2016 was an important step in determining the main reasons for the inefficient management of human resources in the civil service and the involvement of citizens in the civil service. Deficiencies and gaps in the legislation in the field of employment of civil servants in the context of Ukraine's European integration have been identified. For example, researchers highlight the following problems: the problem of inconsistency of standards and procedures of personnel management in the civil service to European practices; the lack of relationship between the classification system of civil service positions and the requirements for professional competence to hold such positions; the problem of insufficient application of scientific approaches and research results for human resources management in the civil service, etc.

The author highlighted the following shortcomings and gaps in the legislation in the field of employment of civil servants: 1) lack of assessment of individual psychological characteristics, physical fitness and health status of candidates for civil service positions; 2) the lack of clear requirements for professional qualifications of civil service positions, which must meet the candidate for civil service; 3 ) the problem of foreign citizenship of civil servants, dual citizenship or participation in terrorist organizations banned in Ukraine; 4) the problem of political influence on civil servants; 5) the problem of compliance with military legislation by civil servants given the difficult military-political situation in our country. Substantiated proposals on ways to solve them are formulated. The scientist proposes to make some changes to the Law of Ukraine "On Civil Service” dated 10.12.2015 № 889-VIII and to exclude part 5 of Article 30 from the content of the Law of Ukraine "On the status of deputies of local councils" dated 11.07.2002 № 93-IV to solve the above problems.

Key words: problems, shortcomings, gaps, employment, civil servants, civil service. 